\title{
PENGEMBANGAN KOMPETENSI MAHASISWA MELALUI EFEKTIVITAS PROGRAM MAGANG KEPENDIDIKAN
}

\author{
1Ismail; Hasan; Musdalifah \\ Email: ${ }^{1}$ smileummaspul@gmail.com
}

\section{Program Studi Pendidikan Bahasa Inggris, STKIP Muhammadiyah Enrekang Indonesia}

\begin{tabular}{ll}
\hline Keyword & Abstract \\
\hline $\begin{array}{l}\text { Pengembangan } \\
\text { Kompetensi; }\end{array}$ & $\begin{array}{l}\text { Aspek terpenting dalam program magang adalah menyiapkan lulusan calon } \\
\text { Efektifitas }\end{array}$ \\
program & mengenali, mengamati sekolah sampai dengan dapat berdiri mengajar di kelas \\
Magang; & sebagai sosok yang dinanti dan dirindu oleh peserta didiknya dibutuhkan proses \\
& panjang. Penelitian ini bertujuan untuk mengungkapkan bagaimana program \\
& magang dapat menguatkan kompetensi calon guru yang terdiri dari 1) \\
& Kompetensi Paedagogik, 2) Kompetensi Profesional, 3) Kompetensi Sosial, dan 4) \\
& Kompetensi Kepribadian. Jenis penelitian ini adalah penelitian kualitatif, dengan \\
& pendekatan fenomenologi. Teknik pengumpulan data menggunakan wawancara, \\
& observasi dan dokumentasi. Teknik analisis data menggunakan analisis interaktif. \\
& Hasil penelitian menunjukkan bahwa Peningkatan kompetensi mahasiswa melalui \\
& program magang meliputi aspek: kompentesi pedagogik, kompentensi profesional, \\
& kompetensi sosial, dan kompetensi kepribadian sosial telah mencapai standar \\
& profesi dan dijadikan sebagai tauladan bagi calon guru. Mahasiswa magang 2 \\
& sudah memiliki konsep dalam menyusun Rencana Proses Pembelajaran (RPP), \\
& yang terdiri dari pengetahuan membuat perencanaan pengajaran, pelaksanaan \\
& pengajaran, sampai pada evaluasi pengajaran, dan bahkan sarana dan prasarana, \\
& serta administrasi kesiswaan. Mahasiswa juga memperoleh kompetensi \\
kepribadian dalam wujud softskill meliputi: keterampilan berkomunikasi, \\
keterampilan beradaptasi dalam pekerjaan, keterampilan mengelola kerja tim, \\
keterampilan bersosialisasi, serta ketelitian dalam bekerja. kompetensi tersebut \\
dapat terinternalisasi di dalam diri mahasiswa sebagai insan akademik dengan \\
ditopang beberapa matakuliah penunjang.
\end{tabular}

\section{PENDAHULUAN}

Kemajuan masa depan bangsa dalam pendidikan ditentukan oleh mahasiswa calon guru yang merupakan insan berharga dan diharapkan akan menjadi pendidik, pembimbing, juga menjadi teladan bagi peserta didiknya. Oleh karena itu, calon pendidik selayaknya memiliki visi dan misi pribadi sebagai seorang guru, dimulai dari konsep mereka tentang karakter dan ciriciri seorang guru profesional yang dimiliki sejak mereka masih belajar di perguruan tinggi.

Kedudukan guru memiliki peran yang sangat penting dalam mencapai 
tujuan pendidikan di sekolah. Tujuan pendidikan tersebut dapat dicapai apabila tenaga pendidik memiliki kompetensi pedagogik, sosial, profesional dan kepribadian yang optimal. Dengan demikian, tugas yang diemban seorang guru tidaklah mudah karena guru yang baik tidak hanya memberi tahu, menjelaskan atau mendemonstrasikan, tetapi juga harus mampu menjadi teladan, menginspirasi, mampu memandang perubahan jauh kedepan (visioner), serta mampu merencanakan apa yang terbaik bagi anak didiknya, (Ismail, 2017a).

Pada dasarnya Kompentesi merupakan deskripsi yang seharusnya dilakukan seseorang dalam pekerjaannya, sebagaimana yang telah dijabarkan dalam Undang-undang nomor 14 tahun 2005 tentang guru dan dosen pasal 1 ayat (10) yang menyatakan bahwa kompentesi adalah seperangkat pengetahuan, keterampilan, dan perilaku yang harus dimiliki, dihayati dan dikuasai oleh guru dan dosen dalam melaksanakan tugas keprofesionalan.

Dengan demikian berarti guru harus memiliki dedikasi yang tinggi terhadap tugas yang diembannya, karena apabila tugas ini diserahkan kepada yang bukan ahlinya maka akan berakibat buruk. Sesuai dengan hadist Rasulullah SAW yang artinya: "Apabila sebuah urusan diserahkan kepada orang yang bukan ahlinya, maka tunggulah saat kehancurannya" (HR. Bukhari-6015). Hal ini menandakan bahwa seorang guru yang kompenten bukan hanya ahli, disiplin, dan berdedikasi saja, tetapi juga harus didasari bahwa tugas guru adalah ibadah (Hidayah, SN., 2017).

Perhatian khusus mengenai pentingnya kompentesi ini, pemerintah mulai sejak tahun 2003, atau sejak lahirnya Undang-undang No. 20 tahun 2003 tentang Sistem Pendidikan Nasional, fokus terhadap peningkatan mutu pendidikan sudah semakin terasa. Pasal 35 Undang-undang ini menyatakan dengan tegas delapan aspek penyelenggaran pendidikan harus dikelola berdasarkan standar tertentu, yakni standar isi, standar proses, standar kompetensi lulusan, standar tenaga kependidikan, standar sarana dan prasarana, standar pengelolaan, standar pembiayaan, dan standar penilaian. Dasar penting lainnya adalah dengan lahirnya Undang-undang no. 14 Tahun 2005 tentang guru dan Dosen yang merupakan penjabaran dari UU sebelumnya. Undangundang ini secara khusus mengatur tentang standarisasi kualifikasi dan kompetensi guru.

Berdasarkan gambaran singkat perkembangan pendidikan guru di tanah air, sudah cukup menjelaskan bahwa upaya dalam meningkatkan ketersediaan dan mutu guru mengalami perjalanan yang cukup panjang, (Achmad, n.d.). Banyak pihak yang menganggap bahwa rendahnya kualitas pendidikan nasional ini tidak lepas dari minimnya kompetensi yang dimiliki guru. Salah satu indikator bahwa pendidikan belum mampu menghasilkan sumber daya manusia yang berkualitas adalah rendahnya daya saing masyarakat. Dijelaskan bahwa Indeks Pembangunan Manusia Indonesia (IPM) untuk 2015 adalah 0.689. Ini menempatkan Indonesia dalam kategori pembangunan manusia menengah, dan peringkat 113 dari 188 negara dan wilayah. Nilai IPM meningkat 30,5 persen dari nilai pada tahun 1990. Hal ini mencerminkan kemajuan yang telah dicapai Indonesia dalam hal harapan hidup saat lahir, rata-rata tahun bersekolah, harapan lama bersekolah dan pendapatan nasional bruto (PNB) per kapita selama periode tersebut. Namun demikian IPM Indonesia menurun tajam ke 0,563 (turun 18,2 persen) bila kesenjangan diperhitungkan. Kesenjangan pendidikan dan harapan hidup saat lahir di Indonesia lebih tinggi dari rata-rata di Asia Timur dan Pasifik, namun Indonesia lebih baik dalam hal 
kesenjangan pendapatan dan gender dibandingkan dengan rata-rata di kawasan ini, (Dunstan, I., 2017).

Hal tersebut kemudian memaksa pemerintah dan lembaga pendidikan untuk memperhatikan kualitas dari pada calon guru. Disamping itu, kecukupan dosen yang bermutu yang mampu menerjemahkan dan melaksanakan kurikulum perkuliahan dengan baik, serta dukungan masyarakat dan semua unsur yang terkait dengan proses penyiapan guru.

Selain hal tersebut, kegiatan lain yang sudah selayaknya diprogramkan institusi atau lembaga pendidikan adalah kegiatan magang atau praktik pengalaman lapangan bagi calon guru, khususnya yang berkaitan dengan teknik pengajaran dan pembelajaran, pengelolaan kelas dan psikologi perkembangan anak. Kegiatan magang ini semata-mata diarahkan guna membentuk kompetensi mahasiswa, sehingga setelah lulus nanti mereka akan memiliki keterampilan serta produktif.

Demikian halnya, Program Studi Pendidikan Bahasa Inggris STKIP Muhammadiyah Enrekang dalam rangka peningkatan mutu lulusan melakukan beberapa upaya, di antaranya menyelenggarakan kegiatan perkuliahan yang efektif dan efisien dengan tujuan untuk membina mahasiswa agar memiliki keahlian dan keterampilan dalam bidang pendidikan Bahasa Inggris. Di samping kegiatan perkuliahan, mahasiswa juga dibekali dengan seperangkat kompetensi melalui pengalaman nyata di lapangan dalam bentuk program magang. Salah satu aspek pentingnya program magang ini adalah untuk menyiapkan lulusan calon pendidik yang profesional diperlukan pentahapan sejak dari kemampuannya mengenali, mengamati sekolah sampai dengan dapat berdiri mengajar di depan kelas sebagai sosok yang dinanti dan dirindu oleh peserta didiknya dibutuhkan proses panjang melalui Program Magang, .

Kegiatan magang merupakan sarana latihan kerja bagi mahasiswa STKIP Muhammadiyah Enrekang dalam meningkatkan pemahaman, penghayatan, dan keterampilan dibidang keguruan. Hal tersebut dimaksudkan untuk meningkatkan kemampuan mahasiswa, serta upaya untuk membentuk sikap dan keterampilan sebagai calon guru yang profesional.

Program magang dijadikan sebagai salah satu upaya untuk menjebatani kesenjangan antara teori yang diperoleh oleh mahasiswa di bangku perkuliahan dengan kondisi profesi yang sebenarnya di lapangan. Kegiatan ini sebagai sarana yang nantinya untuk menunjang dan memperkaya pengalaman mahasiswa dalam mengajar dan sekaligus sebagai sarana untuk mempromosikan dan memasarkan Program Studi Pendidikan Bahasa Inggris kepada masyarakat.

Program Magang 2 bertujuan memantapkan kompetensi akademik kependidikan dan kaitannya dengan kompetensi akademik bidang studi dan menetapkan kemampuan awal calon guru dalam mengembangkan perangkat pembelajaran melalui: penjabaran kurikulum kedalam perangkat pembelajaran yang digunakan guru. Magang adalah bagian penting dan merupakan prakondisi dari sistem penyiapan guru profesional, (Rugaiyah, 2011).

Program magang kependidikan diharapkan menjembatani antara perguruan tinggi dengan lembaga pendidikan. Namun ternyata apa yang diharapkan tidak berjalan sebagaimana mestinya. Mahasiswa magang hanya sekedar lulus mata kuliah namun tidak memiliki arti penting. Sistim pelaksanaan program magang yang telah dilakukan masih belum efektif karena lemahnya koordinasi diantara fihak-fihak yang terlibat, kurang terstruktur, dan kurang 
selektif, sehingga perlu penyempurnaan (Muslih, 2014). Maka dipandang perlu untuk melakukan penelitian tentang efektivitas program magang dalam mengembangkan kompetensi mahasiswa. Sehingga nantinya akan didapat sebuah rekomendasi program magang yang efektif dan sesuai dengan kebutuhan dunia pendidikan, atau yang dikenal dengan link and match. Mahasiswa yang melaksanakan magangpun dapat menerapkan konsep yang diperoleh di bangku kuliah.

Khusus untuk proses magang 2, mahasiswa ditempatkan pada sekolah mitra yang ada di Kabupaten Enrekang selama jangka waktu tertentu, sehingga mereka dapat belajar dan menimba pengalaman dari praktek nyata tentang pengelolaan pendidikan. Selama kegiatan ini berlangsung mahasiswa dibimbing oleh guru pamong di tempat magang, Ketua Program Studi, dosen pembimbing, dan Koordinator Magang dari Program Studi Pendidikan Bahasa Inggris. Dengan Program magang 2 mahasiswa di sekolah, dapat diketahui sejauh manakah teoriteori yang diberikan selama perkuliahan dapat diaplikasikan di tempat magang yang selanjutnya dapat dijadikan perbaikan pada program magang berikutnya.

Dengan menjalankan berbagai kegiatan yang telah diprogramkan secara baik maka mahasiswa yang sedang atau telah melaksanakan program magang 2 akan mampu menelaah kurikulum dan perangkat pembelajaran, strategi pembelajaran, system evaluasi/penilaian dan pengembangan perangkat pembelajaran (silabus, RPP, media pembelajaran, bahan ajar, LKS dan perangkat evaluasi atau bahkan mampu melakukan inovasi dibidang pendidikan, (Ismail, 2017b) . Inovasi yang dimaksud di sini adalah baik dalam metode pembelajaran, media pembelajaran, maupun hal-hal lain yang secara tidak langsung mampu meningkatkan motivasi belajar peserta didik, sehingga diharapkan mereka memenuhi persyaratan kompetensi yang ditetapkan yaitu kompetensi pedagogik, kompetensi profesional, kompetensi kepribadian dan kompentesi sosial.

\section{METODE PENELITIAN}

Jenis penelitian yang digunakan dalam penelitian ini adalah pendekatan survey dan analisa data sekunder dengan metode eksploratif dan deskriptif. Informan penelitian ini adalah mahasiswa Program Studi Pendidikan Bahasa Inggris STKIP Muhammadiyah Enrekang, dan waktu yang dibutuhkan dalam penelitian ini selama 1 bulan, yakni dari Juli 2017 s.d Agustus 2017. Sasaran dalam penelitian ini adalah Mahasiswa yang telah menyelesaikan magang 2 pada Program Studi Pendidikan Bahasa Inggris.

Teknik pengumpulan data dilakukan dengan menggunakan angket menyertakan dokumentasi berupa laporan magang yang dibuat mahasiswa. Selain itu untuk mendukung keabsahan data, maka ditunjang dengan interview/wawancara.

Selama proses magang berlangsung, dilakukan monitoring antara peneliti dengan peserta magang dengan frekuensi dua kali perminggu untuk membahas perkembangan dan kesulitan yang dihadapi peserta dalam proses magang. Langkah berikutnya adalah menguji hasil yang diperoleh dari program magang mulai dari pengumpulan data, kedisiplinan, pengolahan dan penyajian data. Dan yang terakhir adalah mengevaluasi pengalaman yang diperoleh selama proses magang berlangsung.

\section{HASIL dan PEMBAHASAN}

\subsection{Kompetensi Pedagogik}

Mahasiswa Program studi

pendidikan Bahasa Inggris STKIP Muhammadiyah Enrekang pada 
umumnya mendapatkan pengetahuan di bangku kuliah, disamping itu pengetahuan juga diperoleh melalui kegiatan magang di sekolah. Pengetahuan tersebut meliputi: mengetahui pelaksanaan langsung mata kuliah yang dipelajari, mengetahui secara menyeluruh kegiatan di sekolah, mengetahui lebih detail kebutuhan pendidikan di lapangan, mengetahui tentang cara menyusun rencana proses pembelajaran (RPP) yang terdiri dari pengetahuan membuat perencanaan pengajaran, pelaksanaan pengajaran, sampai pada evaluasi pengajaran, dan bahkan sarana dan prasarana, serta administrasi kesiswaan.

Berdasarkan hasil observasi yang dilakukan mengindikasikan bahwa pendidikan dan pelatihan calon guru dalam bentuk program magang mempunyai nilai positif, bukan hanya untuk meningkatkan keterampilan dan keahlian calon guru tetapi dapat meningkat kompetensi pedagogic mahasiswa sebagai calon guru yang lebih baik. Program magang mempunyai kontribusi yang sangat berarti untuk meningkatkan kompetensi dan membuka wawasan calon guru yang lebih luas dan berpikir kritis, kreatif dalam menghadapi tugas dan fungsinya. Dengan kegiatan magang telah banyak perubahan yang terjadi pada diri mahasiswa khususnya dalam menghadapi era global dalam menatap dunia pendidikan dan pengajaran yang berlangsung begitu cepat. Sedangkan disisi lain secara aplikatif dihadapkan oleh berbagai faktor oleh guru, yaitu belum semua guru mampu mengikuti kemajuan yang terjadi di dunia pendidikan. Tentu saja ketidaksiapan sebagian guru menyongsong kemajuan itu bukan mustahil akan berdampak kurang suksesnya kemajuan dunia pendidikan (Kornelius; A. Margono; Hartutiningsih, 2014).

Pembekalan magang yang diberikan kepada mahasiswa dibutuhkan untuk meningkatkan pengetahuan dalam kegiatan magang antara lain: mahasiswa diberikan pengarahan terlebih dulu sebelum magang, panitia dan koordinator magang menjelaskan secara detail kegiatan yang akan dilakukan di tempat magang, dosen pembimbing memberikan bimbingan dengan sungguh-sungguh pada mahasiswa agar perencanaan dan pelaksanaan magang lebih terkoordinir, (Rugaiyah, 2011). Dalam memberikan mata kuliah disesuaikan dengan kondisi riil di lapangan, dan pada mata kuliah Development language teaching media (MK Media Pengembangan Pengajaran Bahasa), Perencanaan dan Simulasi Pembelajaran Bahasa Inggris, classroom management, curriculum and material development, dan microteaching lebih diperdalam.

Berdasarkan hasil analisis temuan pada aspek kompetensi pedagogik diperoleh data bahwa 81,25\% informan menyatakan kompetensi yang diperoleh di Kampus sudah cukup membekali untuk melaksanakan kegiatan magang dan sebanyak $18,75 \%$ responden menyatakan belum cukup memadai. Selanjutnya dapat dilihat pada grafik berikut ini:

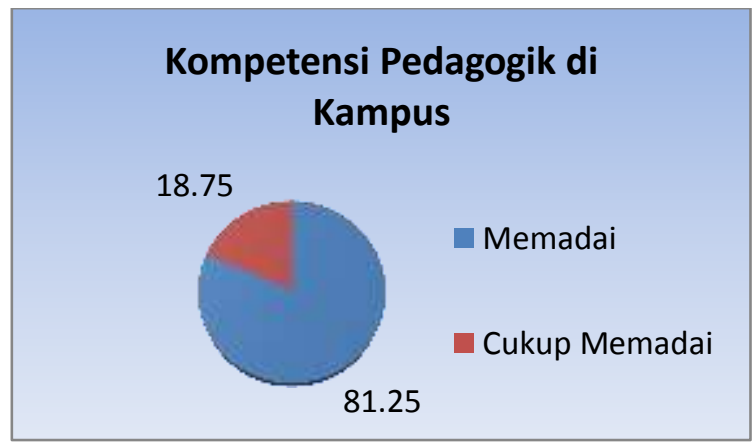

Gambar 1: Kompetensi Pedagogik mahasiswa yang diperoleh dikampus

\subsection{Kompetensi Kepribadian}

Program Magang 2 bertujuan memantapkan kompetensi akademik kependidikan dan kaitannya dengan kompetensi akademik bidang studi dan menetapkan kemampuan awal calon guru 
dalam mengembangkan perangkat pembelajaran melalui: penjabaran kurikulum kedalam perangkat pembelajaran yang digunakan guru. Kompetensi yang diharapkan mahasiswa terkait pelaksanaan magang 2 pada sekolah mitra meliputi: 1. Penelaahan strategi pembelajaran; 2. Penelaahan sistem evaluasi; 3. Perancangan RPP; 4. Pengembangan media pembelajaran; 5 . Pengembangan bahan ajar; dan 6 . Pengembangan perangkat evaluasi.

Dalam menjalankan program
magang,
melaksanakan tugas yang diberikan guru pamong di tempat mereka magang dan sedikit sekali mengalami hambatan. Jika mereka mendapatkan hambatan maka mereka langsung bertanya kepada pegawai yang menugaskan, sharing dengan teman sejawat atau konsultasi langsung kepada Dosen Pembimbing. Khusus kegiatan magang 2 di sekolah, selain menyusun administrasi kesiswaan yaitu menelaah kurikulum, membuat RPP dan tugas lainnya mereka juga melaksanakan kegiatan mengajar sesuai peminatan dan permintaan oleh guru pamong.

Mahasiswa banyak memperoleh keterampilan selama melaksanakan kegiatan magang di sekolah mitra dalam merancang perangkat pembelajaran meliputi: mahasiswa memiliki keterampilan cara membuat silabus, rencana pelaksanaan pembelajaran (RPP), cara mengajar yang baik, dan bahkan cara mengolah nilai.

Disamping itu, mahasiswa juga memperoleh kompetensi kepribadian dalam melaksanakan program magang di sekolah mitra, diantaranya: 1) mahasiswa mengamati perilaku saling menghargai antar warga sekolah. 2) Mengamati sikap dan perilaku warga sekolah, terhadap norma-norma yang dianut (agama, hukum, dan sosial) yang berlaku dalam masyarakat, serta kebudayaan nasional Indonesia yang beragam. 3) Mengamati berbagai strategi berkomunikasi yang efektif, empatik, dan santun, baik secara lisan maupun tulisan di Lingkungan Sekolah. 4) Mengamati komunikasi para guru, staf, dan kepala sekolah dari sudut komunikasi yang efektif, empatik, dan santun pada peserta didik dengan bahasa yang khas dalam interaksi pembelajaran yang terbangun secara klasikal mulai dari: a. Penyiapan kondisi psikologi peserta didik, b. Memberikan pertanyaan atau tugas sebagai undangan kepada peserta didik untuk merespon, c. Respon peserta didik, dan d. Reaksi guru terhadap respon peserta didik, (Haryudin, 2016). Kompetensi Keperibadian yang mereka dapatkan dalam wujud softskill meliputi: keterampilan berkomunikasi, keterampilan beradaptasi dalam pekerjaan, keterampilan mengelola kerja tim, keterampilan bersosialisasi, serta ketelitian dalam bekerja.

\subsection{Kompetensi Sosial}

Kemampuan sosial sangat di butuhkan bagi seorang guru yang telah mampu untuk berkomunikasi dan berinterakasi secara efektif dan efisien sesuai dengan karakteristik peserta didik, maka materi yang disampaikan kepada peserta didik jelas tersampaikan sehingga peserta didik paham dengan penjelasan guru. Guru mampu memupuk semangat kebersamaan, berusaha saling terbuka, dan membangun persaudaraan dengan adanya diskusi kelompok sehingga terbentuk ikatan emosional dengan peserta didik lainnya. Guru mampu menciptakan iklim belajar yang menyenangkan sehingga peserta didik dapat belajar dengan nyaman karena selain banyak mengajar, guru juga mampu memberi inspirasi agar peserta didik dapat mengembangkan kreativitas melalui kegiatan belajar sehingga peserta didik memperoleh pengalaman belajar.

Guru mampu untuk berkomunikasi dan berinterakasi secara efektif dan efisien sesama guru terlihat 
dengan kecakapan individu guru dalam menjalin hubungan sesama guru sehingga tidak mengalami kesulitan dalam menyesuaikan diri dan dapat terlibat dalam kegiatan sekolah. Guru menjalin kerjasama yang baik dengan sesama guru misalnya menetapkan peraturan tata tertib apa yang diperbolehkan dan apa yang dilarang oleh peseta didik sehingga peserta didik tidak kebingungan dan mengetahui baik buruknya setiap tindakan.

Guru mampu untuk
berkomunikasi verbal dan berinterakasi secara efektif dan efisien yang sangat penting saat membangun persahabatan dengan orangtua atau wali peserta didik melalui kerjasama antara guru dan peserta didik yang menyebabkan terjadinya pertukaran informasi antara guru dan orang tua atau wali peserta didik mengenai kejadian yang melingkupi diri peserta didik dalam kehidupan sehari-harinya baik dalam lingkungan sekolah, keluarga, maupun masyarakat dalam rangka mengawasi aktivitas keseharian belajar dan perilaku peserta didik. Hal ini, bisa terjadi misalnya guru bertemu dengan orangtua atau wali peserta didik ketika mendekati waktu ujian atau hal yang berkaitan dengan masalah peserta didik yang penting.

$$
\text { Guru mampu untuk }
$$

berkomunikasi dan berinterakasi secara efektif dan efisien dengan masyarakat, terlihat ketika guru memasuki perkumpulan dan turut serta dalam kejadian yang penting dalam lingkungannya seperti pelaksanaan upacara di hari besar Nasional di luar lapangan sekolah maka secara otomatis masyarakat akan ikut berpartisipasi dalam kegiatan sekolah tersebut dengan pihak sekolah.

\subsection{Kompetensi Pengembangan Kepribadian dan Keprofesionalan}

Pada kompetensi pengembangan kepribadian dan keprofesionalan (profesional) yaitu: a. mahasiswa terampil dalam mengorganisasikan urutan materi. b. Mahasiswa terampil dalam menyiapkan bahan pembelajaran.c.mahasiswa terampil merumuskan indikator pembelajaran. d. mahasiswa menguasai pengetahuan keguruan. e. mahasiswa mengusai pengetahuan yang diajarkan. Hasil temuan tersebut sesuai dengan SKGP (Standar Kompetensi Guru Pemula) sekolah dasar Direktorat Pembinaan Pendidikan Tenaga Kependidikan dan Ketenagaan Perguruan Tinggi (2006:1516) yaitu kompetensi pengembangan kepribadian dan keprofesionalan (profesional) dijabarkan sebagai berikut: 1) mampu memahami diri sendiri dan orang lain, sehingga dapat belajar memahami dan memberikan apresiasi terhadap orang lain. 2) Mampu rnengembangkan system nilai dan kode etik guru. 3) memiliki keyakinan yang kuat dan dedikasi terhadap profesi keguruan di bidang pendidikan dasar. 4) mampu memberdayakan masyarakat untuk kepentingan pendidikan.

Berdasarkan data yang diperoleh bahwa mahasiswa memperoleh keterampilan pada kegiatan magang di sekolah relevan dengan perkuliahan yang diperoleh dikampus dan pada kegiatan inilah mahasiswa memiliki keterampilan yang lebih spesifik, seperti: Penelaahan strategi pembelajaran; 2. Penelaahan sistem evaluasi; 3. Perancangan RPP; 4. Pengembangan media pembelajaran; 5 . Pengembangan bahan ajar; dan 6 . Pengembangan perangkat evaluasi. Pengalaman inilah yang menjadikan mahasiswa lebih kompeten.

Di antara mata kuliah yang relevan dan dominan adalah mata kuliah Pengembangan materi dan kurikulum (Curriculum and Material Development) dan mata kuliah Micro Teaching serta Classroom Management. Hal ini 
dipandang sangat perlu untuk meningkatkan content dan proses pembelajaran yang mengacu kepada perkembangan kurikulum sehingga memiliki relevansi dengan pelaksanaan pembelajaran di sekolah.

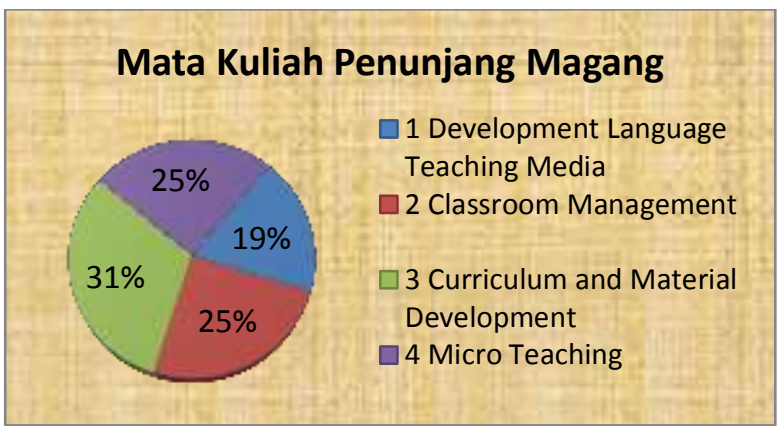

Gambar 2: Mata kuliah penunjang kegiatan magang di Sekolah

Dalam hal perubahan perilaku dan nilai yang diperoleh mahasiswa, dari segi cara berpakaian, mahasiswa terbiasa menggunakan pakaian formal, bagi lakilaki menggunakan kemeja dan celana panjang non jeans, bagi perempuan terbiasa menggunakan rok dan blouse yang sopan (tidak ketat dan menutup aurat). Untuk kehadiran, mahasiswa hadir lebih awal dan pulang sesuai waktunya bahkan terkadang melebihi waktu yang ditentukan. Mahasiswa juga terbiasa disiplin, jujur, kompak dalam bekerjasama, santun dan hormat pada atasan, peka terhadap situasi dan kondisi. Nilai-nilai tersebut dapat terinternalisasi di dalam diri mahasiswa sebagai insan akademik.

Berdasarkan observasi, mahasiswa peserta magang di SMA Muhammadiyah Alla Kabupaten Enrekang telah memenuhi keempat kompetensi tersebut. Untuk kemampuan pedagogik ditunjukkan dari mahasiswa telah mampu memahami karakteritik peserta didik karena pada dasarnya peserta didik memiliki perbedaan dalam pengetahuan, kecerdasan, emosional, bakat, dan bahasa. Sehingga, mampu mengatur kelas dengan baik yakni memberikan metode belajar berdasarkan karakteristik dan kemampuan peserta didik.

Mahasiswa peserta magang mampu memahami dengan baik rancangan kurikulum yang telah disusun secara lengkap dan mengkaitkannya dengan konteks kehidupan sehari-hari peserta didik. Mahasiswa mampu mempertautkan materi yang akan diajarkan dengan tingkat pengetahuan peserta didik berdasarkan materi yang telah diajarkan sebelumnya dan berkorelasi.

Selain kedisiplinan, mahasiswa juga terlatih dan menjadi terbiasa untuk jujur dalam melaksanakan pekerjaan, contohnya dalam pembuatan laporan. Begitupula dalam bekerjasama dengan kelompok sejawat, staf dan pimpinan tempat mahasiswa melakukan magang, berkontribusi dan terlibat langsung dalam kegiatan di sekolah, selalu melaksanakan tugas yang diberikan, bertanggung jawab menyelesaikan tugas dengan baik, dan peka terhadap situasi dan kondisi, konsisten dalam bekerja, komitmen, perilaku sopan santun dan hormat pada pimpinan di sekolah, dan mampu bekerjasama.

\section{KESIMPULAN}

Guru adalah salah satu faktor pendidikan yang memegang peranan penting dalam pelaksanaan program pengajaran di sekolah. Dibalik kesuksesan peserta didik, pasti ada guru yang hebat. Profesi guru adalah profesi yang mulia karena mampu mendidik, mengajar, membimbing, mengarahkan, melatih, menilai, mengevaluasi bahkan menjadi tauladan atau contoh bagi peserta didik yang dapat diterapkan dalam konteks kehidupan sehari-hari. Oleh karena itu, perlu peningkatan mutu guru dengan meningkatkan kemampuan pedagogik, kemampuan kepribadian, dan kemampuan sosial.

Peningkatan kompetensi mahasiswa melalui program magang 
telah mencapai standar profesi dan dijadikan sebagai tauladan bagi calon guru. Mahasiswa magang 2 sudah memiliki konsep dalam menyusun Rencana Proses Pembelajaran (RPP), yang terdiri dari pengetahuan membuat perencanaan pengajaran, pelaksanaan pengajaran, sampai pada evaluasi pengajaran, dan bahkan sarana dan prasarana, serta administrasi kesiswaan. Mahasiswa juga memperoleh kompetensi kepribadian dalam wujud softskill meliputi: keterampilan berkomunikasi, keterampilan beradaptasi dalam pekerjaan, keterampilan mengelola kerja tim, keterampilan bersosialisasi, serta ketelitian dalam bekerja. Kompetensi tersebut dapat terinternalisasi di dalam diri mahasiswa sebagai insan akademik dengan ditopang beberapa matakuliah penunjang.

\section{DAFTAR PUSTAKA}

[1] Achmad, F. et. a. (n.d.). Penguatan kompetensi calon guru melalui program magang pada mahasiswa PGSD FKIP UMS. Seminar Nasional Pendidikan PGSD UMS \& HDPGSDI Wilayah Jawa, 37-44.

[2] Haryudin, A. (2016). Apprenticeship II. Retrieved from acepharyudin.dosen.stkipsiliwangi.ac.id/.. ./BAHAN-MATERI-MAGANG

[3] Ismail, I. (2017a). MEMBANGUN LANDASAN JATI DIRI PENDIDIKAN DAN MENETAPKAN KOMPETENSI AKADEMIK KEPENDIDIKAN. Research Gate, 1(4), 42. https://doi.org/10.13140/RG.2.2.17 340.64641

[4] Ismail, I. (2017b). Rencana Pembelajaran Semester (Rps) Sap Dan Kontrak, Dengan Sistem Penilaian Otentik Dilengkapi Dengan Format Dan Rubrik Penilaian.
Rencana Pembelajaran Semester MK Academi Writing (Semester IV-Genap), 1(1), 43. https://doi.org/https://doi.org/10.1 3140/RG.2.2.36463.2

[5] Kornelius; A. Margono; Hartutiningsih. (2014). Pendidikan dan Pelatihan Guru dalam Meningkatkan Kualitas Pendidik di SMP Negeri 27 Sendawar Kabupaten Kutai Barat. eJournal Administrative Reform, 2(3), 1811-1823.

[6] Dunstan, I. (2017). Indeks Pembangunan Manusia Indonesia Meningkat tapi Kesenjangan Masih Tetap Ada http://www.id.undp.org/content/ind onesia/id/home/presscenter/pressr eleases/2017/03/22/indonesia-shuman-development-index-rises-butinequality-remains-.html

[7] Muslih, M. (2014). Analisis Efektifitas Program Magang untuk Sinkronisasi Link and Match Perguruan Tinggi dengan Dunia Industri. Jurnal manajemen \& bisnis (Studi Terhadap Program Magang Pada Fakultas Ekonomi Prodi Manajemen, 14(1), 6476.

[8] Peraturan Menteri Pendidikan Nasional Nomor 16 Tahun 2007 Tanggal 4 Mei 2007 mengenai Standar Kualifikasi Akademik Dan Kompetensi Guru

[9] Rugaiyah. 2011. Pengembangan Kompetensi Mahasiswa Melalui Magang. Jurnal Manajemen Pendidikan. 209-219 